\title{
THE AMALGAMATION OF INDO-ISLAMIC ARCHITECTURE OF THE DECCAN
}

\author{
SHARMILA DURAI \\ Department of Architecture, School of Planning \& Architecture, \\ Jawaharlal Nehru Architecture \& Fine Arts University, India
}

\begin{abstract}
A fundamental proportion of this work is to introduce the Islamic Civilization, which was dominant from the seventh century in its influence over political, social, economic and cultural traits in the Indian subcontinent. This paper presents a discussion on the Sultanate period, the Monarchs and Mughal emperors who patronized many arts and skills such as textiles, carpet weaving, tent covering, regal costume design, metallic and decorative work, jewellery, ornamentation, painting, calligraphy, illustrated manuscripts and architecture with their excellence. It lays emphasis on the spread of Islamic Architecture across India, embracing an ever-increasing variety of climates for the better flow of air which is essential for comfort in the various climatic zones. The Indian subcontinent has produced some of the finest expressions of Islamic Art known to the intellectual and artistic vigour. The aim here lies in evaluating the numerous subtleties of forms, spaces, massing and architectural character which were developed during Muslim Civilization (with special reference to Hyderabad).

Keywords: climatic zones, architectural character, forms and spaces, cultural traits, calligraphic designs.
\end{abstract}

\section{INTRODUCTION}

India, a land enriched with its unique cultural traits, traditional values, religious beliefs and heritage has always surprised historians with an amalgamation of varying influences of new civilizations that have adapted foreign cultures. The advent of Islam in India was at the beginning of 11th century [1]. Islam, the third great monotheistic religion, sprung from the Semitic people and flourished in most parts of the world. In the late 6th century, Prophet Mohammed who was the founder of Islam pursued his theological enquiries and traversed the caravan routes from Mecca into Palestine and later leading the first adherents of the new monotheism which arose into a great civilization called the Islamic Civilization and gave rise to the Muslim era.

Muslims first invaded the Western Coast of India when Arab traders (in the seventh century) came to the coast of Kerala and Konkan Gujarat to trade; this marked the beginning of the Islamic Empire all over India. In history, it is evident that whenever any civilization invades another civilization, it influences its political, social, economic and cultural practices [3]. When Muslims invaded India, it was rich in its culture, literature and architecture, and yet the Islamic civilization could empower the Indian subcontinent to produce some of the finest expression of Islamic architecture in India. The Sultanate period and the Mughals have patronized many arts and skills such as paintings, carpet weaving, manuscripts, calligraphy, jewellery, textiles and architecture, which reached their peak during the Islamic period. The Sultanate period has seen five successive dynasties namely: the Khiljis, the Tughlaqs, the Sayyids, the Lodhis and the Suries [4]. All of these dynasties have produced some of the finest examples of arts and architecture throughout India. Later in the years of The Mughal period, the dominance of arts and architecture throughout India is clearly evident in its history, which came to be known as the Indo-Islamic heritage. 


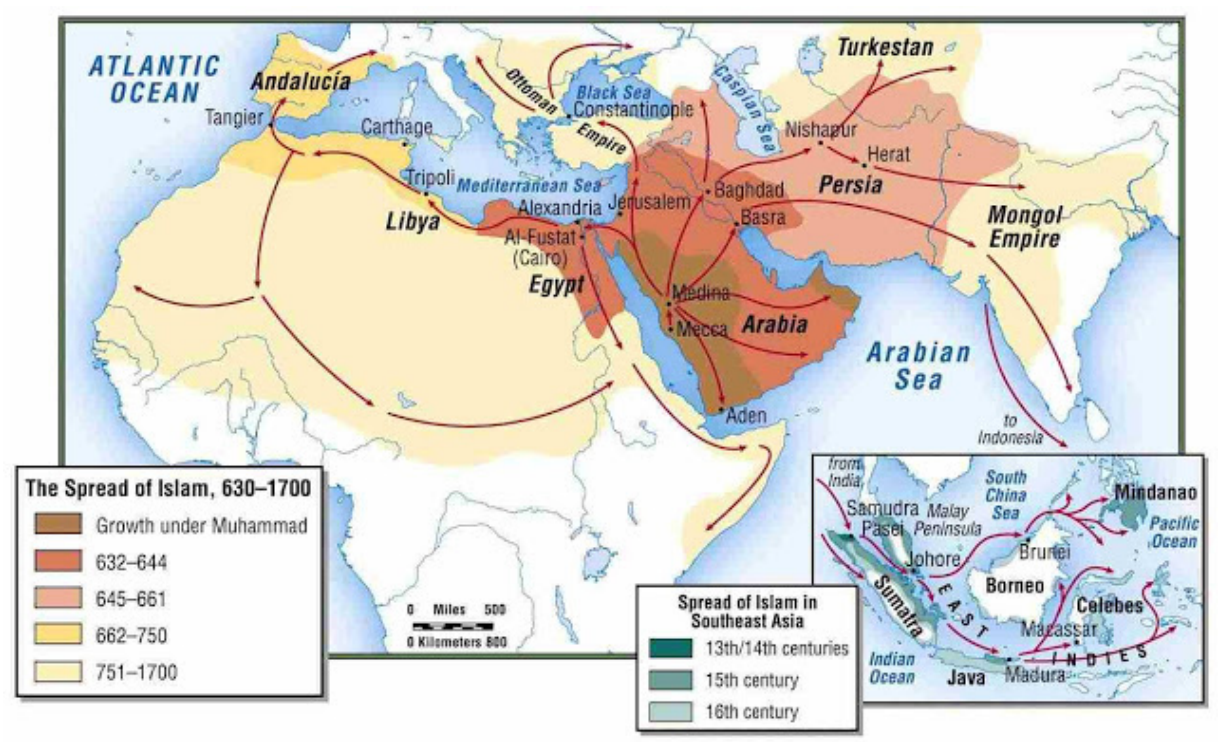

Figure 1: Spread of Islam all over the world [2].

\section{ISLAMIC ARCHITECTURE}

No other architectural style other than Islamic architecture is designated by concordance with a religion. Islamic architecture may be seen as the one great product of two streams of development: one in Mediterranean, and the other in South-Central Asia [1]. India has produced more notable buildings than all the other countries that came under the influence of Islam. The architectural style of a place derives its character from the people, their habits, their lifestyle, their ideals and their habitat.

\subsection{The Indian subcontinent}

Islam came to India in successive waves of military invasions from the eleventh to thirteenth century, challenging the established religions of Hinduism and Buddhism [5] with its fundamentally different perspectives. The earliest foot prints of Islam were in the Sindh Valley of India. As quoted by author Percy Brown, "Islamic architecture in India arrived in its true colour and achieved its greatest splendour."

\subsection{Indo-Islamic architecture}

The first century of Islam is influenced with byzantine undertones, and a glimpse of Syrian and Egyptian architecture [6]. As dictated by the religion, the Muslim elites required large buildings for their mosques and tombs which gave rise to different forms and elements in their constructions. Unbaked bricks and other forms of earth construction as building materials were extensively used.

In 1527 when the Mughal Empire had its foothold in India an everlasting mark on Indian architecture was left. The buildings that evolved during provincial period were systematic and symmetrical in style. Triple domes and extensive courtyards were the prominent design elements, with the employment of the interlocking arabesque concept, in which each element 
stands on its own and is perfectly integrated with its main structure - for example thick walls and corbeled arches [8]. Heavy lintels were combined with eclectic assortments of motifs from other influences. During the Mughal era, Islamic architecture was fused with Hindu architecture and blended into the Indian style [6]. The numerous constructions that originated in Muslim architecture in India were mosques, mausoleums, forts, madrasahs and tombs, and the significant architectural elements used were for the grandeur of arches, domes, minarets and vaults. The buildings constructed from 1526 to 1764 achieved remarkable glory in IndoIslamic architecture.

\subsection{Styles of Islamic architecture in the Indian subcontinent}

\subsubsection{Imperial style}

The earliest appearance of Islamic architecture in India is referred to as the imperial style. The style of this period is also called the early Indo-Islamic style. The existing buildings were converted into mosques with the elements of ruins from Hindu temples [9]. As quoted by Sir John "a mix of Indian and Arabic style of architecture emerged and developed into a peerless form of art and architecture." The palaces were elaborately decorated and embellished with arches and domes. Floral patterns and other Hindu motifs were used widely [8].

\subsubsection{Provincial style}

In this style of architecture which lasted for a period of two-hundred-and-fifty years, they created buildings with the locally available materials, combining the regional styles with the typical Muslim features such as domes, arches, the minarets and the mihrabs. Initially they constructed on the ruins of Hindu, and Jain temples, and later they derived their own style in building art [9].

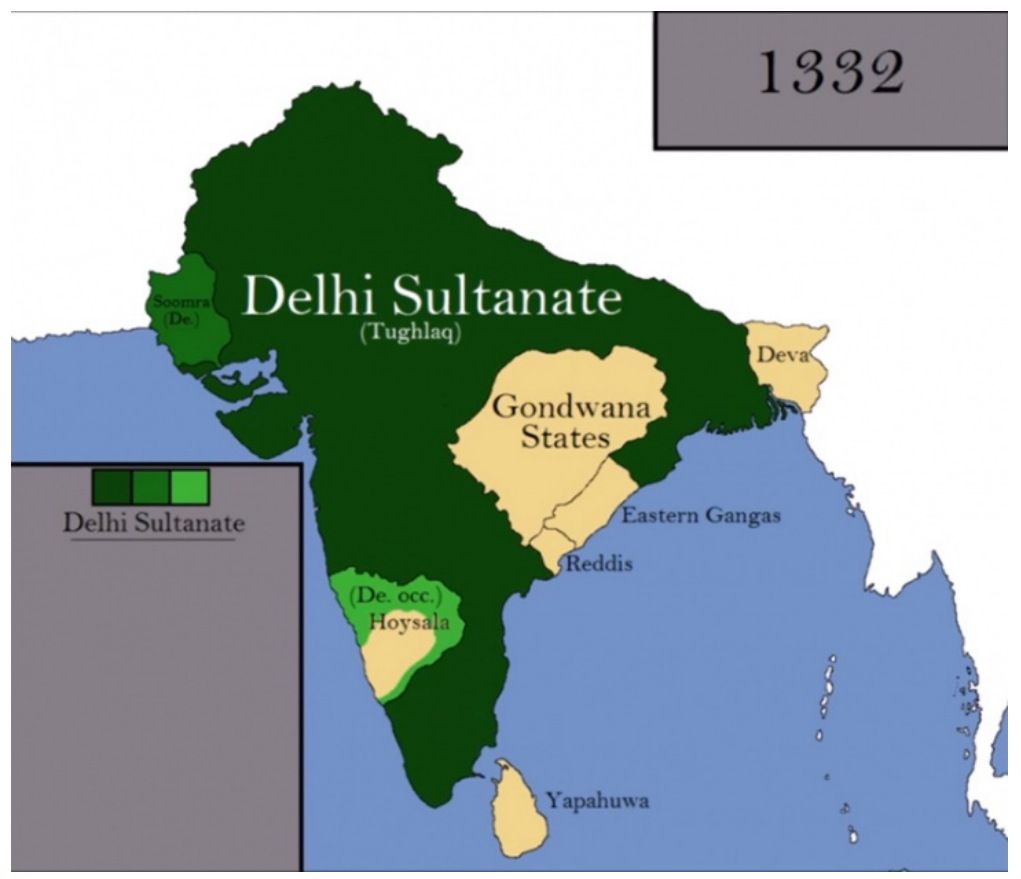

Figure 2: Spread of Delhi Sultanate in India [2]. 


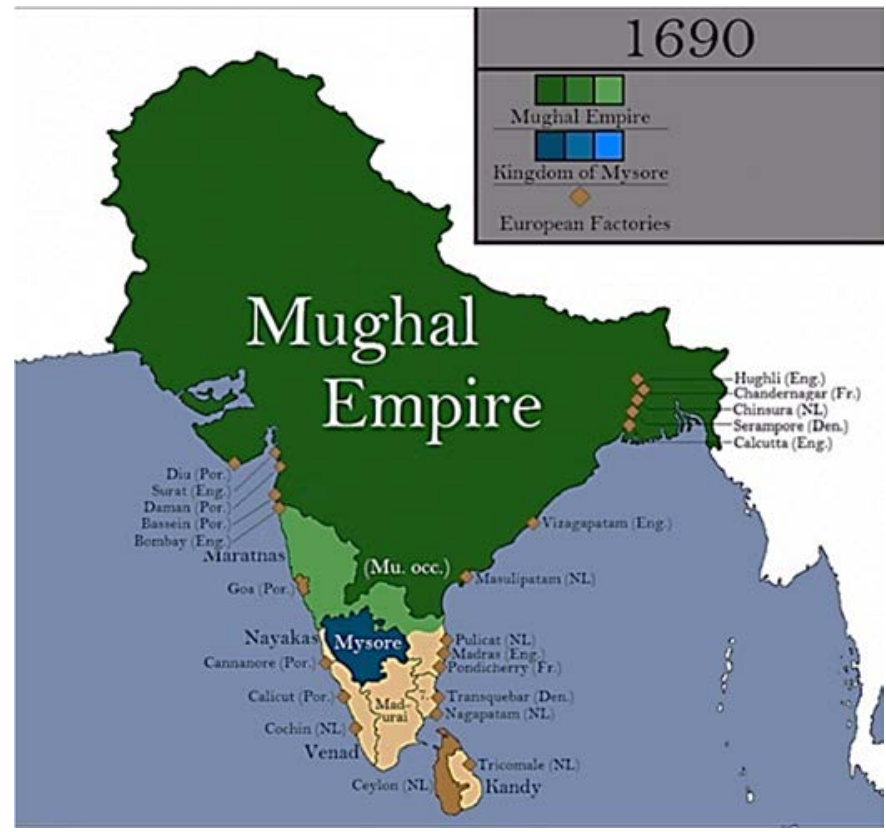

Figure 3: Spread of the Mughal Empire in India [2].

Table 1: Chronological order of the Indo-Islamic period [9].

\begin{tabular}{|l|c|c|}
\hline \multicolumn{1}{|c|}{ Dynasties } & Period & Style of Architecture \\
\hline Conquest by Muhammad Ghori & 1192 & - \\
\hline The Slave Dynasty & $1206-1290$ & Imperial style \\
\hline The Khalji Dynasty & $1290-1320$ & Imperial style \\
\hline The Tughlaq Dynasty & $1320-1398$ & Imperial style \\
\hline The Lodi Dynasty & $1413-1414$ & Provincial style \\
\hline The Sayyid Dynasty & $1414-1450$ & Provincial style \\
\hline The Mughal Dynasty begins & $1526-1540$ & Mughal style \\
\hline The Sur Dynasty & $1540-1555$ & Mughal style \\
\hline The Mughal again & $1555-1857$ & Mughal style \\
\hline
\end{tabular}

\subsubsection{The Mughal style}

The Mughal style is the style of architecture that flourished in India under the patronage of the Mughal Empire from the mid-16th to the 17th century [9]. It is a unique blend of IndoIslamic and Persian style with Turkish influences. The buildings were excellent and remarkably symmetrical in form and uniform in pattern with intricate ornamentation. 


\subsection{Types of buildings in Islamic architecture in the Indian subcontinent}

\subsubsection{Mosque}

Mosques are the places of congregation where men gather to offer prayers. They are also called "masjids" and known as a place for prostration. They are basically large columned halls known as hypostyle halls and in some of the mosques, Madrasahs are also a part of the same building. The open courtyard inside a mosque was called a "Sahn", with a fountain inside of it which was a respite in the hot areas and the water could be used for a cleansing ritual (ablution) before offering prayers. Another important element used in the mosque was the "mihrab". It is the niche in the wall that indicates the direction of Mecca towards which all the Muslims pray. It's usually a shallow niche, and the wall on to which the Mihrab is located, is called a Qibla which indicates the direction of Mecca. The most visible element of the mosque is the "minaret", the tower which is either adjacent or attached to the mosque from which the call to prayer is announced. The most important (but inessential) element of Islamic architecture and a part of the mosque is the "dome" which is also known as "qubba" in Muslim architecture [11]. It is a symbolic representation of the vault in heaven, it is usually found surmounting the Qibla wall. Mosques often have one or multiple domes. They are rich in decoration with geometrical motifs. Calligraphy is also the most visible decorative element in mosques.

\subsubsection{Forts}

They were palaces; a place of accommodation on a larger and more comprehensive scale, thus forming a city within a city. They were built for the purpose of defence to protect the monarchs and their people from their enemies.

The most ambitious project of Akbar, the Mughal emperor regime was Fateshpur sikhri. It was a new capital specially selected site, twenty-six miles west of Agra conceived to be a great complex of palaces, mosques, residential quarters, official spaces and market places. A city containing no streets, but an arrangement of terraces and courtyards grouped to numerous palaces and pavilions. The material used for the construction was sand stone which was available locally. We can also see the influences of different regional architecture of Gujrat and Punjab as the craftsmen from different places were brought to work who made their own distinguished architectural mark on the capital [5].

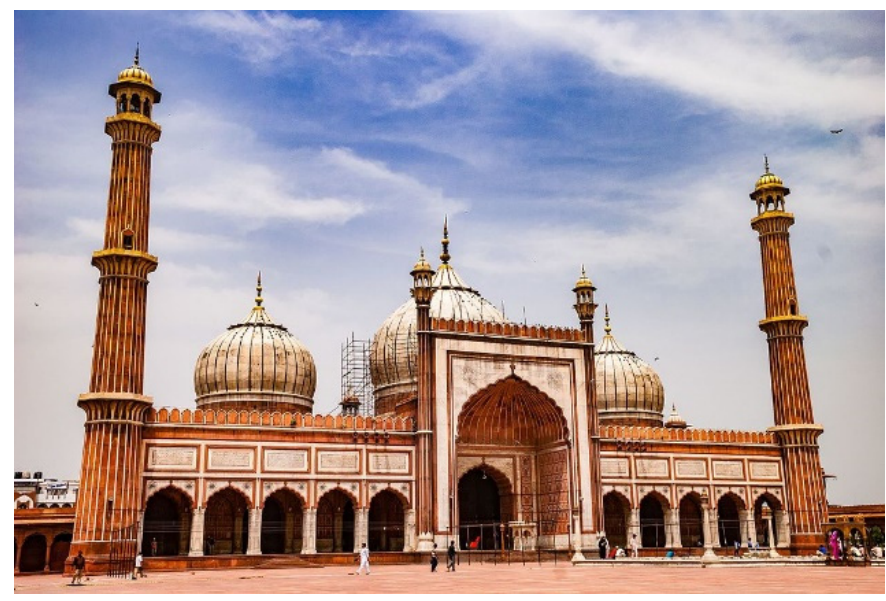

Figure 4: Jama Masjid [5]. (Source: https://en.wikipedia.org/wiki/Jama_Masjid,_Delhi.) 


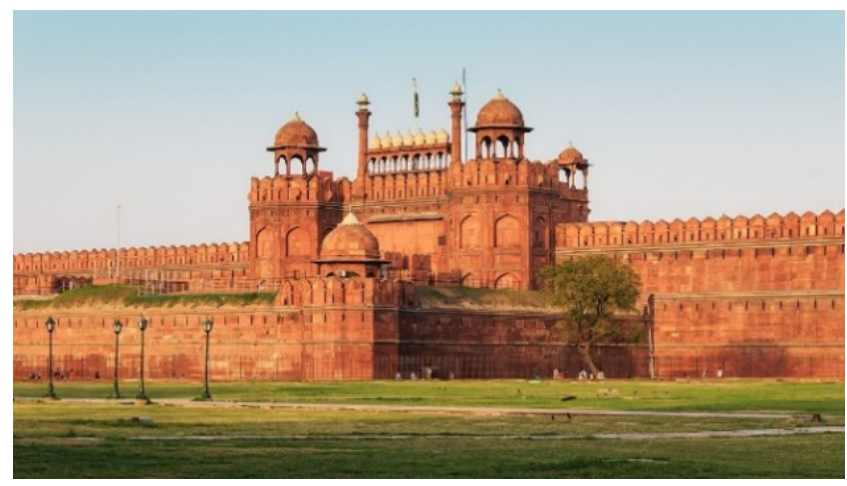

Figure 5: Red Fort [5]. (Source: https://en.wikipedia.org/wiki/Red_Fort.)

\subsubsection{Tombs}

Among the architectural marvels that were built during the Islamic rein in India, the most wonderful, and beautiful structure was the tomb of Mumtaz Mahal, the Taj Mahal, which is an integrated complex of many structures.

White domed marble, large gardens, pools with fountains reflecting the light, landscape, and four tall standing minarets surrounding the structure imply a symmetrical and a balanced form. This proves the elegance of the Indo-Islamic style of architecture. It is a perfect example of an architectural accomplishment of the Mughal building art.

\section{A CASE STUDY OF THE PROVINCIAL STYLE IN ISLAMIC ARCHITECTURE: THE DECCAN - GOLCONDA (1512-1687)}

\subsection{Introduction}

Hyderabad: a fortress city of Golconda on the banks of river Musi, a city rich in culture, affluence, heritage and architecture was found under the Qutub Shahi dynasty and was built

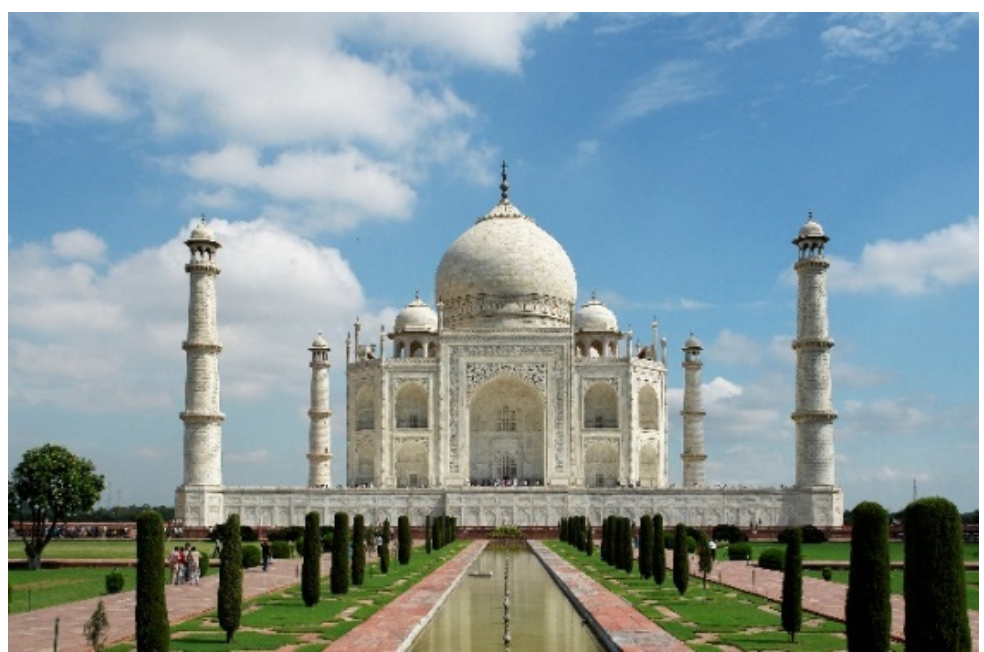

Figure 6: Taj Mahal [5]. (Source: https://en.wikipedia.org/wiki/Taj_Mahal.) 


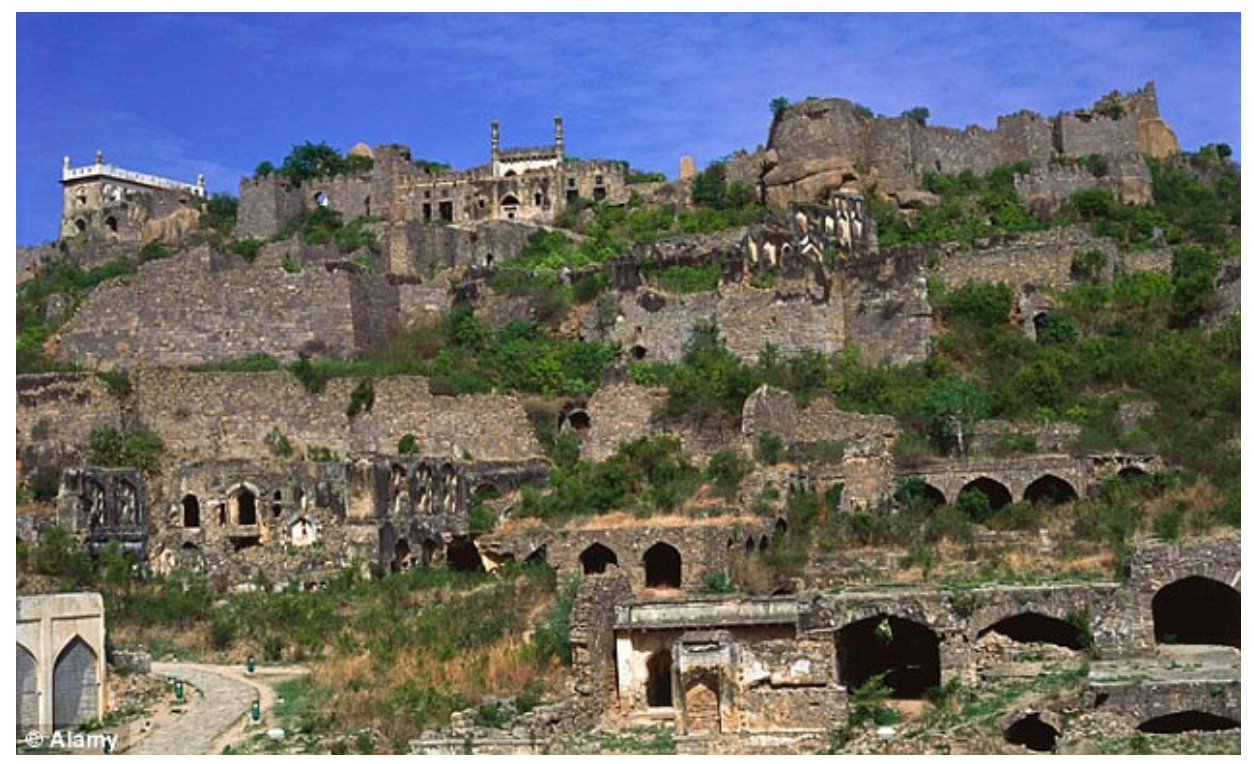

Figure 7: Golconda Fort overview [9].

by Muhammad Quli Qutub Shah at end of 15th century which has gained a remarkable place in the history of Islamic heritage cities. Later in 1666, the Mughal Emperor Aurangzeb laid a seize on Golconda and the city fell into ruins. Lastly to be ruled by The Nizams, who were successful again in bringing back the glory to Golconda. Heritage Monuments inherited in Hyderabad are Golconda Fort, Charminar, Mecca Masjid, Paigah Tombs, Chowmalla Palace, Mojamzahi Market, Taramati Baradari, etc. The most notable among them is Golconda Fort.

Golconda Fort is one of the finest examples of forts in India, and is a pride of Hyderabad. Selection of the site itself is strategically done to achieve this aim. Context of Mangalavaram hill and its orientation has given Qutub-Shahi kings an edge to establish the powerful kingdom of Golconda [5]. For decades, this fort has served as a strong administrative, and a residential capital for seven Qutub-Shahi kings. It is evident that only because of Golconda, the Qutub-Shahi kingdom has gained its fame and restored its place in the significant history of Indo-Islamic heritage.

\subsubsection{Cultural traits}

In the design and construction of the fort the major factors that influenced were its sociocultural aspects. There are two communities in Islam - SHIAS and SUNNIS.

i. Rituals: In Islam, the Shias celebrate MUHARRAM as a major festival. The Rangeen Mahal and a stage on the left of it were built so that Muharram could be celebrated in a prestigious manner.

ii. Lifestyle: QAWALI is one of the Muslim practices where songs are sung and celebrated in a unique way. Rangeen Mahal was built only for the purpose, where all rituals could be enjoyed. Qutub-Shahi's were more liberal in nature as many Hindu influences could be seen throughout the fort.

iii. Marriage: In Islam, the concept of "Polygamy" was followed. The King had many wives and hence there was a need for many palaces, and many spaces were required to accommodate his concubines in the fort. 
iv. Death: The spaces such as mosques and tombs had been designed in the fort to bury their dead and also to perform the rituals during the process of death. A space for the mortuary bath, a space to read the last prayers - Janaza ki namaaz, a place for burial, and a place to cleanse oneself after the burial were all constructed within the fort, which was situated near the Nagina Bagh that lead to the Qutub-Shahi tombs.

v. Gosha system: Islam, a religion which is conservative designated the privacy for women, where women were not allowed to be seen by any other man other than their own husbands, hence the Gosha system prevailed [6]. The queen was concealed from the public and yet she used to have a place beside the King in the Durbar hall, Rani Mahal and Rangeen Mahal. The architectural elements like internal balconies, and intricately designed windows with jaalis, and jhorakhas were seen.

vi. Architectural spaces: The fort had four forms of architecture - military form, civic form, religious form and a commercial form [12]. The architecture of these forms is not isolated, but are intimately intermingled all over the fort, and it is not possible to separate one form from the other.

\subsubsection{Architectural character}

Zoning: three types of zones are identified in the fort - one is private and one is a semi-public space. The other is visually open and one is a visually closed zone.

The Qutub-Shahi rulers inherited the Bahmani style of architecture [12]. All the buildings were functionally rich with a lot of ornamentation and grandeur. ARCUATE type of constructions visible in most parts of the fort. The construction of private staircases for the King is of TRABEATED type. PERISTYLE halls are seen in the design of the Rani Mahal. Hypostyle halls, which were a significant character in Islamic architecture are absent in the fort [5]. The Akkanna - Madanna Office was used by both the ministers of the last king of the Qutub-Shahi dynasty, Abul Hasan and Tana Shah, a secretarial building comprising of rows of columns known as arcades connecting it to the other structures on its South.

\subsection{Characteristic features}

\subsubsection{Hydrology}

One of the most important aspects of Golconda is its hydrology. According to the study, Qutub-Shahi used a five-tiered fort wall to ensure a stable water supply in times of peace and war. The flow of water comes from a bund at Durgam Cheruvu which is in the northern side of Golconda. The channel then goes to the edge structure of Malaka Cheruvu, and another channel recurs at the edge of the Qutb-Shahi tomb quadrangle overlooking Ibrahim Bagh Cheruvu (northern side), then traverses a different course. The channel ultimately disappears near Pan Makthaand and reappears yards away from Husain Shah Wali-Dargah where it skirts an old wall which acts as an aqueduct for low lying areas, remaining oblivious. The barely concealed canal continues till the rear end of the Qutb-Shahi complex. The canal is blended into the contours of the land and emerged near Jamalikunta before entering the Katora Houz on the eastern side. Once inside the fort, the water goes to the lower areas through a gravity system and a Persian water wheel was used to pump up the water where the royals had baths, fountains, toilets, and other amenities, which were at higher levels. The highest point of Golconda is $609 \mathrm{~m}$ above sea level, while portions of Durgam Cheruvu are at $610 \mathrm{~m}$ above sea level. Much of water channel is between $495 \mathrm{~m}$ and $505 \mathrm{~m}$ above sea level [12]. 


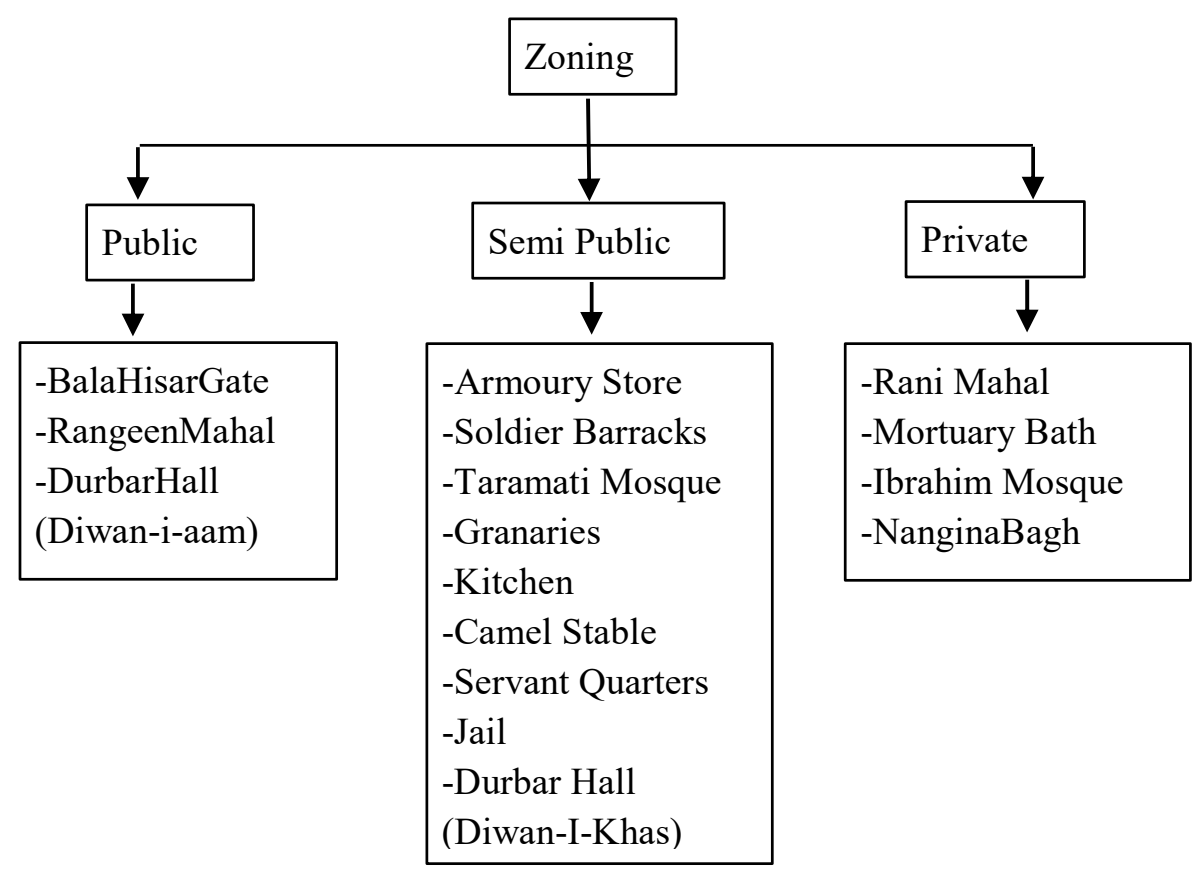

Figure 8: Flow chart showing the zoning of Golconda Fort.

\subsubsection{Defence}

To warn the king and ministers present in the durbar hall, there are 5 fortification walls, which rise to a height of over $12 \mathrm{~m}$ with different construction details as a part of the defence strategy [4]. There is a visual connectivity between the Durbar hall and the Balahisar gate, and the Durbar hall to the bastion on the southwest. The fort walls were made very thick with mud filled in between the stonewalls which are broad with a rampart on top and a stone parapet which was not visible from outside and was used to safe guard the fort to send warning when needed. Planning and location of the 8 gates are done in such a way that, even though the enemies enter from one side, the royal family can escape from the other. The walls are buttressed with 87 bastions which rise to a height of 15 to 18 meters. Each of these bastions was surmounted by cannons of varying calibre rendering the fort impregnable and making it one of the strongest amongst the forts of medieval Deccan. The key point was concealment by enforcement of guards at strategic points [13]. There are different spaces in the fort such as Armory storage, soldier barracks, gun powder room, and hot oil pits used for defence. There was a deep moat around the second fort wall with crocodiles in it. There is a secret underground tunnel beneath the Rani Mahal that is at the foot of the hill with one end leading to the "Durbar Hall", and the other to the "Charminar". There are meandering pathways in the fort that confuse the enemies attacking it and give the defenders sufficient time to react. There are so many secret tunnels and shortcuts only known to the guards, which are a crucial part of security systems [13].

\subsubsection{Acoustics}

The ancient architects understood both the facets of sound echo as well as amplification that form an integral part of sound physics [7]. They used materials known for their sound 
reflection properties like clay pots and pans and blended them into the building material [13]. The process of sound reflection to reach the durbar hall is: From the Balahisar gate, the amplified sound is re-reflected through the Armory storage building; From the Armory storage, it gets reflected on to the office buildings; From the office buildings to Taramati mosque, and then to Ibrahim mosque and finally to the Durbar hall. There is a series of 10 steps on the terrace of Durbar Hall where the guard would hear the warning signals from the Balahisar gate along with the voice of the person speaking on top of the steps which was echoed and reflected in the whole fort by the four minarets built on the four corners of the parapet wall. In the royal palace, if one whispers into the corner of the wall, it could be heard perfectly through the walls in the opposing corner, designed to catch conspirators.

\subsubsection{Climatology}

The Golconda fort is located in Ibrahim Bagh, which is in the western part of Hyderabad. The coordinates of Hyderabad: longitude - 78.4-degrees east, latitude - 17.38-degrees north. The current climate of Hyderabad features composite (semi-arid) climate, where the days are hot and dry, and the nights are cool and breezy. The wind flow in summers is mostly from the southwest, and in winter it is from the northeast. During the construction of the fort in the 12 th -17 th century, the climate of the place was very sunny. It was constructed on a rocky hill with sparse vegetation around it, mandating the need for cooling. Based on the climatic conditions of the particular area, different cooling techniques were used in the fort.

1. Passive solar control - this technique focuses on the heat gain control, and heat dissipation in order to improve indoor air quality. In the fort, this technique is found in the Durbar hall where the west side has very tiny openings and the thickness of the wall on South is about $7 \mathrm{~m}$.

2. Courtyards - these are central spaces for a building, which are open to sky are used for a stack effect, courtyards are located in Akkanna-Madanna offices and in the Rani Mahal.

3. Orientation of the buildings and their openings - the buildings are oriented in accordance to wind flow, sun path, and other climatic conditions like humidity etc. The openings are also given based on these factors. The Durbar hall is oriented in such a way that there is proper airflow in it. There are very few openings on the west and a $7 \mathrm{~m}$ thick wall for thermal comfort.

4. Cross ventilation - the rooms were designed in accordance to the circulation and air flow movement with openings on both sides.

\subsection{Individual buildings}

\subsubsection{Durbar Hall}

It is a wind-swept pavilion located on the top most part of the fort. In this, we observe both Arcuate and Trabeated Styles. It is divided into two parts:

\subsubsection{Diwan-I-Aam (Public):}

This is the lower part of the Durbar hall where the King ascends his throne to announce verdicts to the commoners. It is a raised chamber with a triple arch. There is a central arch in front of the entrance, where the King would sit, and the Queen will occupy her space on his left (at an opening not visible to the general public). There are two kinds of staircases - an open staircase for the King, and a closed staircase is for the Queen.

The Baradari shows yet another engineering marvel - natural air-conditioning provided by a gap in the double walls, which sucks in the air, and releases it with accumulated pressure 
into the chambers. On the south of Baradari, there is a retiring room for the King. This is also the coolest amongst all the rooms, where there is a flow of east-west winds in the summer from the western opening.

\subsubsection{Diwan-I-Khas (Semi-Public):}

This is the first floor of the Durbar hall that the King would occupy with his fellow ministers to discuss social, and political issues. On the uppermost terrace stands a stone throne, used for acoustical purposes. Sounds made were reflected because of the four small minarets on the corners of the high parapet wall. There are two bedrooms located on either side of DiwanI-Khas for the King to retire. One to be used in the summer, and the other in the winter [14]

\subsubsection{King's private pathway}

The path which was only open to the King is of a thousand steps build in granite stone with a riser of $10 \mathrm{~cm}$. It is trabeated in construction and connects Rani Mahal and Durbar Hall.

\subsubsection{Construction details}

Stairs are simultaneously laid with the courses for a parapet wall. Lime mortar is used as for binding the stones. The masonry used is rubble masonry for the parapet walls (with small stones). For columns - the stone dimensions used are approximately $80 \mathrm{~cm} \times 20 \mathrm{~cm} \times 20 \mathrm{~cm}$, and the bond that is made is designed such that three stretchers were used for every header. Walls were designed as load bearing structures, and many secret passages were located below the pathway [14].

\section{CONCLUSION}

The Indo-Islamic Architecture in the sub-continent of India has reached its peak, leaving a historical footprint in the heritage of India. The buildings and monuments that have survived the ravages of time are still in extant in India and have attained international recognition. The challenge now is to restore, revive, learn about, and conserve the history while retaining the ancient teachings which need preservation. To progress in the area of conserving heritage, we have to change our paradigm of architecture with a new approach respecting the climate, culture and traditions of the region. Therefore, creating an ecological, cultural sustainability, and to protect and conserve the rich heritage which had been passed on to us as a treasure. Hyderabad's heritage is an old one and vivid as its nearly 427 years old history and though today Hyderabad is the fastest developing city with modern IT hub, the successful and intangible attributes of the Islamic rulers left a legacy of rich cultural heritage, monumental architectural glory and a versatile city for the next generations to be inspired and invigorated.

\section{REFERENCES}

[1] Fletcher, B., History of Architecture, Bloomsbury Publishing.

[2] www.pinterest.com/pin/304978205994764568/. Accessed on: 12 Feb. 2018.

[3] http://shodhganga.inflibnet.ac.in/bitstr. Accessed on: 16 Feb. 2018.

[4] Grover, S., Islamic Architecture in India, 2nd ed., CBS Publishers.

[5] www.scribd.com/document/89652968. Accessed on: 1 Feb. 2018.

[6] https://en.wikipedia.org/wiki/Islam/. Accessed on: 19 Jan. 2018.

[7] https://en.wikipedia.org/wiki/Golkonda. Accessed on: 19 Jan. 2018.

[8] Brown, P., Indian Architecture (Islamic Period), Kiran Book Agency, 2012.

[9] http://asi.nic.in/asi_monu_alphalist_andhra.asp. Accessed on: 16 Jan. 2018.

[10] www.indianetzone.com $/ \overline{3} 7 /$ provincial_indo_islamic_architecture.htm. Accessed on: 13 Jan. 2018. 
266 Islamic Heritage Architecture and Art II

[11] www.slideshare.net/ashoknene/building-materials-of-ancient-india. Accessed on: 2 Jan. 2018.

[12] Nayeem, M.A., The Heritage of the Qutub Shahis of Golconda and Hyderabad, Hyderabad Publishers, 2006.

[13] www.thehindu.com/todays-paper/tp-features/tp-youngworld/ancient-acousticdevices-in-the-fort/article3227478.ece. Accessed on: 26 Dec. 2018.

[14] Studio Work on Golconda Fort by Students of School of Planning \& Architecture, JNAFAU, Hyderabad, India. 